\title{
Recent Advances Towards the Inclusion of Flow Chemistry within the Undergraduate Practical Class Curriculum
}

\author{
Philippa B. Cranwell* \\ Department of Chemistry, University of Reading, Whiteknights Campus, Reading, RG6 6AD, UK \\ p.b.cranwell@reading.ac.uk
}

Received: 13.10 .2020
Accepted: 19.10 .2020
Published online: 29.10 .2020
DOI: $10.1055 /$ s-0040-1719539; Art ID: so-d2222-sto
License terms: CC
2020. The Author(s). This is an open access article published by Thieme under the
terms of the Creative Commons Attribution-NonDerivative-NonCommercial-License,
permitting copying and reproduction so long as the original work is given appropriate
credit. Contents may not be used for commercial purposes or adapted, remixed,
transformed or built upon. (https://creativecommons.org/licenses/by-nc-nd/4.0/)

Key words flow chemistry, practical chemistry, teaching resources

The expansion of flow chemistry as a means for undertaking a chemical reaction has developed rapidly over recent years. When teaching chemistry to undergraduate students, one aspect that has to be addressed is the core subject-knowledge required to function as a chemist, usually taught through lectures. In addition, chemistry is a practical subject; therefore, the laboratory-based skills that students learn and will require upon graduation also need consideration. Traditionally, batch chemistry has dominated the practical laboratory curriculum because, within an industrial setting, completing a reaction using batch chemistry has been the norm. However, in recent years flow chemistry has started to become more ubiquitous within the pharmaceutical industry and fine chemical production, ${ }^{1}$ therefore undergraduate programs have started to amend their practical provision to reflect this. ${ }^{2-4}$ In recent years there have been a number of practical classes designed that utilise continuous-flow analysis and flow-injection analysis procedures, ${ }^{5-16}$ as well as construction of inexpensive microfluidic chips ${ }^{17-19}$ for use both within the undergraduate curriculum and to engage high school students with chemistry. ${ }^{20}$ However, the number of experiments that can be used upon preparative scale are much smaller in number. Examples include Fischer esterification, ${ }^{21,22}$ methylation of

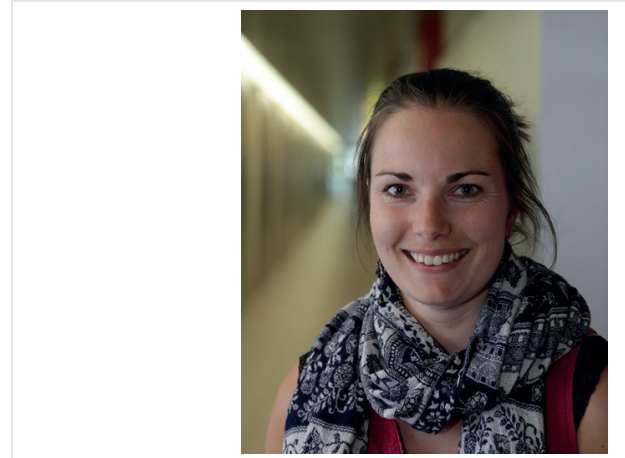

Dr Cranwell is an Associate Professor of Organic Chemistry at the University of Reading. She undertook her PhD studies under the supervision of Professor Steven Ley at the University of Cambridge, and was a postdoctoral research assistant in the group of Professor Erick Carreira at ETH Zürich. She has a keen interest in understanding how students learn, particularly in relation to student misconceptions and how they arise, and she has published work relating to the language used when teaching organic chemistry. She has contributed extensively to the development of new chemistry programmes and re-invigoration of existing programmes, and has a keen interest in ensuring that the chemistry taught within the undergraduate curriculum remains relevant and incorporates the latest technological and scientific developments.

2-napthol, ${ }^{23}$ Hofmann rearrangement, ${ }^{21}$ Knoevenagel condensation, ${ }^{21}$ electrophilic aromatic substitution, ${ }^{21}$ PaalKnorr pyrrole synthesis, ${ }^{21}$ Diels-Alder cycloaddition ${ }^{21}$ and synthesis of azo dyes and disulfides. ${ }^{24}$ Some examples showcasing more recently developed reactions are discussed further in this Spotlight. This field is in its infancy; therefore, this Spotlight should not be considered exhaustive but rather a starting point for any practical class developer looking to include examples of flow chemistry. As this field develops, it is likely that more reactions utilising flow chemistry that are suitable for an undergraduate laboratory will be disclosed over the coming years. 


\section{Abstracts}

(A) A number of reactions using flow photochemistry suitable for an undergraduate practical class have been disclosed, ${ }^{25-27}$ but only two will be showcased here. The first is a photopinacol coupling of benzophenone $(\mathbf{1})^{28}$ and the second a thiol-alkene coupling, ${ }^{29}$ based on previous work by Tyson et al. ${ }^{30,31}$ In both cases, students compared conversion into, and yields of, the desired product between the flow and batch process.
(B) Examples of reactions showcasing green chemistry under flow conditions include the synthesis of 5-hydroxymethylfurfural (6) from fructose (5) ${ }^{32}$ and the conversion of reclaimed vegetable oil into biodiesel (not shown). ${ }^{33}$
(C) Oxidation reactions under flow conditions on a preparation scale have been developed by Kairouz and Collins ${ }^{34}$ and by the Leadbeater group ${ }^{21}$ based on work developed by the Jamison group. ${ }^{35}$ In both cases, a benzylic aldehyde was oxidised to a methyl ester using aqueous $\mathrm{NaOCl}$ in the presence of tetrabutylammonium bromide. In the case of Kairouz and Colins, a range of aldehydes were oxidised and students were able to compare the flow and batch processes.
(D) A ring-closing metathesis reaction ${ }^{36,37}$ to form cyclopentene $\mathbf{1 0}$ from diethyl diallylmalonate (9) on preparative scale, suitable for undergraduate students under flow conditions has been reported. ${ }^{21,22}$ In this case, a short silica plug was required to separate the products from the metathesis catalyst.
(E) A Suzuki-Miyaura cross-coupling ${ }^{21,22}$ between bromobenzene (11) and phenylboronic acid (12) on preparative scale under flow conditions, and suitable for undergraduate students, has been achieved in high yield. To avoid clogging of the reactor system by precipitation of the biaryl product (13), the product stream was intercepted with ethyl acetate, in which the product readily dissolves.

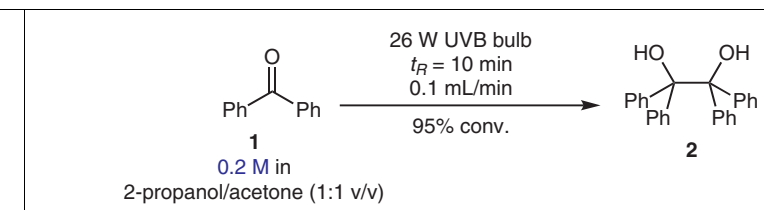

2-propanol/acetone (1:1 v/v)

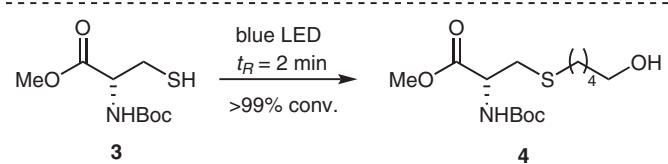

3

4-penten-1-ol (1.5 equiv)

$\mathrm{Ru}(\mathrm{bpy})_{3}\left(\mathrm{PF}_{6}\right)_{2}(1 \mathrm{~mol} \%)$

$p$-toluidine ( 0.5 equiv) $\mathrm{MeCN}$

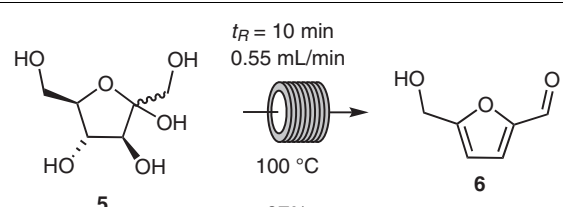

5
$0.2 \mathrm{M}$

$97 \%$

TEAB (7.7 equiv)

$5 \% \mathrm{H}_{2} \mathrm{SO}_{4}(6 \mathrm{~mL})$<smiles>[R7]c1cc(C=O)ccc1Br</smiles>

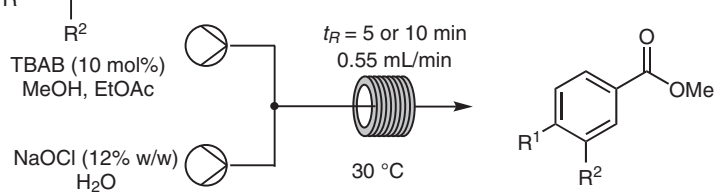

$\mathrm{H}_{2} \mathrm{O}$

$\mathrm{R}^{1}=\mathrm{CN}, \mathrm{R}^{2}=\mathrm{H}(\mathbf{8 a})$ up to $99 \%$ $\mathrm{R}^{1}=\mathrm{H}, \mathrm{R}^{2}=\mathrm{NO}_{2}$ (8b) up to $99 \%$

$\mathrm{R}^{1}=\mathrm{CN}, \mathrm{R}^{2}=\mathrm{H}(7 \mathrm{a})$

$\mathrm{R}^{1}=\mathrm{H}, \mathrm{R}^{2}=\mathrm{NO}_{2}(\mathbf{7 b})$

$\mathrm{R}^{1}=\mathrm{NO}_{2}, \mathrm{R}^{2}=\mathrm{H}(7 \mathrm{c})$

$\mathrm{R}^{1}=\mathrm{Br}, \mathrm{R}^{2}=\mathrm{H}(\mathbf{7 d})$

$\mathrm{R}^{1}=\mathrm{NO}_{2}, \mathrm{R}^{2}$

$\mathrm{R}^{1}=\mathrm{Br}, \mathrm{R}^{2}=\mathrm{H}(\mathbf{8 d})$ up to $99 \%$

(1)




\section{References and Notes}

(1) Baumann, M.; Moody, T. S.; Smyth, M.; Wharry, S. Org. Process Res. Dev. 2020, DOI: 10.1021/acs.oprd.9b00524.

(2) Blanco-Ania, D.; Rutjes, F. P. J. T. J. Flow Chem. 2017, 7, 157.

(3) König, B.; Kreitmeier, P.; Hilgers, P.; Wirth, T. J. Chem. Educ. 2013, 90, 934

(4) Wietsma, J. J.; van der Veen, J. T.; Buesink, W.; van den Berg, A.; Odijk, M. J. Chem. Educ. 2018, 95, 267.

(5) Stults, C. L. M.; Wade, A. P.; Crouch, S. R. J. Chem. Educ. 1988, 65, 645.

(6) McDiffett, W. F.; Veening, H.; Comte, R. F. J. Chem. Educ. 1972 , 49, 510.

(7) Ramos, L. A.; Prieto, K. R.; Cavalheiro, É. T. G.; Cavalheiro, C. C. S. J. Chem. Educ. 2005, 82, 1815.

(8) Hauser, P. C.; Cates, N. E. J. Chem. Educ. 1996, 73, 191.

(9) Davis, L. C. J. Chem. Educ. 1993, 70, 511.

(10) Hansen, E. H.; Ruzicka, J. J. Chem. Educ. 1979, 56, 677.

(11) McClintock, S. A.; Weber, J. R.; Purdy, W. C. J. Chem. Educ. 1985, $62,65$.

(12) Stults, C. L. M.; Kraus, P. R.; Ratanathanawongs, S. K.; Patton, C. J.; Crouch, S. R. J. Chem. Educ. 1989, 66, 1060.

(13) Agustini, D.; Bergamini, M. F.; Marcolino-Junior, L. H. J. Chem. Educ. 2018, 95, 1411.

(14) Economou, A.; Papargyris, D.; Stratis, J. J. Chem. Educ. 2004, 81, 406.

(15) Petrozzi, S. J. Chem. Educ. 2009, 86, 1311.

(16) Gliński, M.; Ulkowska, U.; Iwanek, E. J. Chem. Educ. 2016, 93, 1623.

(17) Vangunten, M. T.; Walker, U. J.; Do, H. G.; Knust, K. N. J. Chem. Educ. 2020, 97, 178.
(18) Piunno, P. A. E.; Zetina, A.; Chu, N.; Tavares, A. J.; Noor, M. O.; Petryayeva, E.; Uddayasankar, U.; Veglio, A. J. Chem. Educ. 2014, 91, 902.

(19) Feng, Z. V.; Edelman, K. R.; Swanson, B. P. J. Chem. Educ. 2015, 92, 723.

(20) Hemling, M.; Crooks, J. A.; Oliver, P. M.; Brenner, K.; Gilbertson, J.; Lisensky, G. C.; Weibel, D. B. J. Chem. Educ. 2014, 91, 112.

(21) Leadbeater, N. E. An Introduction to Flow Chemistry: A Practical Laboratory Course; Vapourtec: Suffolk, UK, 2013.

(22) Cranwell, P. B.; Harwood, L. M.; Moody, C. J. Experimental Organic Chemistry, 3rd ed; Wiley: Weinheim, 2017.

(23) Tundo, P.; Rosamilia, A. E.; Aricò, F. J. Chem. Educ. 2010, 87, 1233.

(24) Kuijpers, K. P. L.; Weggemans, W. M. A.; Verwijlen, C. J. A.; Noël, T. J. Flow Chem. 2020, DOI: 10.1007/s41981-020-00118-1.

(25) Hoffmann, H.; Tausch, M. W. J. Chem. Educ. 2018, 95, 2289.

(26) Gano, J. E.; Gano, A. J.; Garry, P.; Sekher, P. J. Chem. Educ. 2002, $79,1361$.

(27) Taber, D. F.; Paquette, C. M. J. Chem. Educ. 2013, 90, 1105.

(28) Volpe, K.; Podlesny, E. E. J. Chem. Educ. 2020, 97, 586.

(29) Santandrea, J.; Kairouz, V.; Collins, S. K. J. Chem. Educ. 2018, 95, 1073.

(30) Tyson, E. L.; Niemeyer, Z. L.; Yoon, T. P. J. Org. Chem. 2014, 79, 1427.

(31) Tyson, E. L.; Ament, M. S.; Yoon, T. P.J. Org. Chem 2013, 78, 2046.

(32) Simeonov, S. P.; Afonso, C. A. M. J. Chem. Educ. 2013, 90, 1373.

(33) Leibfarth, F. A.; Russell, M. G.; Langley, D. M.; Seo, H.; Kelly, L. P.; Carney, D. W.; Sello, J. K.; Jamison, T. F. J. Chem. Educ. 2018, 95, 1371.

(34) Kairouz, V.; Collins, S. K. J. Chem. Educ. 2018, 95, 1069.

(35) Leduc, A. B.; Jamison, T. F. Org. Process Res. Dev 2012, 16, 1082.

(36) Trnka, T. M.; Grubbs, R. H. Acc. Chem. Res. 2001, 34, 10.

(37) Fürstner, A. Angew. Chem. Int. Ed. 2000, 39, 3012. 